\title{
Comment on 'Strong reduction of AGO2 expression in melanoma and cellular consequences'
}

M Sand ${ }^{\star}, 1$, D Georgas ${ }^{1}$, S Hessam ${ }^{1}$ and F G Bechara ${ }^{1}$

${ }^{1}$ Dermatologic Surgery Unit, Department of Dermatology, Venereology and Allergology, Ruhr-University Bochum, Gudrunstrasse 56, 44791 Bochum, Germany

Sir,

We would like to congratulate Völler et al (2013) on their recent study showing an unchanged mRNA AGO2 expression in melanoma and a strong reduction of AGO2 expression on protein level. This goes along with the findings in our study on the miRNA processing machinery performed in melanoma, which likewise has previously shown an unchanged mRNA AGO2 expression level in melanoma (Sand et al, 2012c). Interestingly, in contrast to melanoma skin cancer, mRNA AGO2 expression levels in epithelial skin cancer (both cutaneous squamous cell and basal cell carcinoma) were significantly higher $(P<0.05)$ compared with healthy controls (Sand et al, 2010, 2012a, b). Although we do agree with the authors that a deregulation of microRNA (miRNA) was observed in several types of cancer and particularly in skin cancer, with reference to our previous studies we do not agree that changes in the miRNA processing enzymes have not been analysed until today as stated in their abstract (Sand et al, 2009, 2011, 2012d, e, 2013; 2014; Sand and Skrygan, 2014).

\section{REFERENCES}

Sand M (2014) The pathway of miRNA maturation. Methods Mol Biol 1095: 3-10.

Sand M, Gambichler T, Sand D, Altmeyer P, Stuecker M, Bechara FG (2011)

Immunohistochemical expression patterns of the microRNA-processing enzyme

Dicer in cutaneous malignant melanomas, benign melanocytic nevi and dysplastic melanocytic nevi. Eur J Dermatol 21(1): 18-21.

Sand M, Gambichler T, Sand D, Skrygan M, Altmeyer P, Bechara FG (2009) MicroRNAs and the skin: tiny players in the body's largest organ. J Dermatol Sci 53(3): 169-175.

Sand M, Gambichler T, Skrygan M, Sand D, Scola N, Altmeyer P, Bechara FG (2010) Expression levels of the microRNA processing enzymes Drosha and dicer in epithelial skin cancer. Cancer Invest 28(6): 649-653.

Sand M, Sand D, Altmeyer P, Bechara FG (2012a) MicroRNA in non-melanoma skin cancer. Cancer Biomark 11(6): 253-257.

Sand M, Skrygan M (2014) Expression profiling of components of the miRNA maturation machinery. Methods Mol Biol 1095: 61-71.

Sand M, Skrygan M, Georgas D, Arenz C, Gambichler T, Sand D, Altmeyer P, Bechara FG (2012b) Expression levels of the microRNA maturing microprocessor complex component DGCR8 and the RNA-induced silencing complex (RISC) components argonaute-1, argonaute-2, PACT, TARBP1, and TARBP2 in epithelial skin cancer. Mol Carcinog 51(11): 916-922.

Sand M, Skrygan M, Georgas D, Sand D, Gambichler T, Altmeyer P, Bechara FG (2012c) The miRNA machinery in primary cutaneous malignant melanoma, cutaneous malignant melanoma metastases and benign melanocytic nevi. Cell Tissue Res 350(1): 119-126.

Sand M, Skrygan M, Georgas D, Sand D, Hahn SA, Gambichler T, Altmeyer P, Bechara FG (2012d) Microarray analysis of microRNA expression in cutaneous squamous cell carcinoma. J Dermatol Sci 68(3): 119-126.

Sand M, Skrygan M, Sand D, Georgas D, Gambichler T, Hahn SA, Altmeyer P, Bechara FG (2013) Comparative microarray analysis of microRNA expression profiles in primary cutaneous malignant melanoma, cutaneous malignant melanoma metastases, and benign melanocytic nevi. Cell Tissue Res 351(1): 85-98.

Sand M, Skrygan M, Sand D, Georgas D, Hahn SA, Gambichler T, Altmeyer P, Bechara FG (2012e) Expression of microRNAs in basal cell carcinoma. Br J Dermatol 167(4): 847-855.

Voller D, Reinders J, Meister G, Bosserhoff AK (2013) Strong reduction of AGO2 expression in melanoma and cellular consequences. Br J Cancer 109(12): $3116-3124$

*Correspondence: Dr M Sand; E-mail: michael.sand@ruhr-uni-bochum.de Published online 20 February 2014

(C) 2014 Cancer Research UK. All rights reserved 0007-0920/14

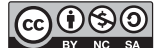

http://creativecommons.org/licenses/by-nc-sa/3.0/
B) $\cap$ OPEN 0

\section{Reply to comment on: strong reduction of AGO2 expression in melanoma and cellular consequences}

D Völler ${ }^{1}$ and A Bosserhoff ${ }^{\star}, 1$

${ }^{1}$ Institute of Pathology, University of Regensburg, Franz-Josef Strauss Allee 11, 93053 Regensburg, Germany Sir,

We are grateful for the feedback regarding our article 'Strong reduction of AGO2 expression in melanoma and cellular consequences' (Völler et al, 2013b). In this study, we discovered a melanoma-specific modulation of AGO2, a member of the miRNA-processing cascade. Moreover, we demonstrated that AGO2 reduction is a direct trigger for the deregulated miRNA pattern in melanoma.

The reduced AGO2 protein amount was observed in melanoma cell lines as well as tissue samples of primary tumours and metastasis. Interestingly, AGO2 reduction was not detectable at mRNA expression level, which indicates a further processing of the AGO2 mRNA transcript in melanoma.

Previous studies analysing the enzymes of the miRNA-processing cascade in cancer were either focused on the mRNA level (e.g., Sand et al, 2012; Jafari et al, 2013) or did not connect the deregulation with a disordered miRNA pattern (e.g., Ma et al, 2011; Grund et al, 2012; Jafarnejad et al, 2013; Völler et al, 2013a). Therefore, we stated that 'Deregulation of miRNA expression was observed in several types of cancer, but changes in the miRNAprocessing enzymes have not been analyzed until today'. However, this statement would have to be focused on the enzyme AGO2 and analysis on protein level in melanoma. We apologize that the current statement is too general as the authors of the previous comment correctly stated.

\section{REFERENCES}

Grund SE, Polycarpou-Schwarz M, Luo C, Eichmuller SB, Diederichs S (2012) Rare Drosha splice variants are deficient in microRNA processing but do not affect general microRNA expression in cancer cells. Neoplasia 14(3): 238-248.

Jafari N, Dogaheh HP, Bohlooli S, Oyong GG, Shirzad Z, Alibeiki F, Asl SH, Zargar SJ (2013) Expression levels of microRNA machinery components Drosha, Dicer and DGCR8 in human (AGS, HepG2, and KEYSE-30) cancer cell lines. Int J Clin Exp Med 6(4): 269-274

Jafarnejad SM, Sjoestroem C, Martinka M, Li G (2013) Expression of the RNase III enzyme DROSHA is reduced during progression of human cutaneous melanoma. Mod Pathol 26(7): 902-910.

Ma Z, Swede H, Cassarino D, Fleming E, Fire A, Dadras SS (2011) Up-regulated Dicer expression in patients with cutaneous melanoma. PLoS One 6(6): e20494.

Sand M, Skrygan M, Georgas D, Arenz C, Gambichler T, Sand D, Altmeyer P, Bechara FG (2012) Expression levels of the microRNA maturing microprocessor complex component DGCR8 and the NA-induced silencing complex (RISC) components argonaute-1, argonaute-2, PACT, TARBP1, and TARBP2 in epithelial skin cancer. Mol Carcinog 51(11): 916-922.

Völler D, Ott C, Bosserhoff A (2013a) MicroRNAs in malignant melanoma. Clin Biochem 46: 909-917.

Völler D, Reinders J, Meister G, Bosserhoff A (2013b) Strong reduction of AGO2 expression in melanoma and cellular consequences. Br J Cancer 109(12): 3116-3124.

*Correspondence: Dr A Bosserhoff; E-mail: Anja.Bosserhoff@klinik.uni-regensburg.de Published online 20 February 2014

(c) 2014 Cancer Research UK. All rights reserved 0007-0920/14

http://creativecommons.org/licenses/by-nc-sa/3.0/ 